\title{
The Time of Our Lives: A Perspective from the Keystone IV Conference
}

\section{David Loxterkamp, MD}

We often experience time as a commodity-in excess for those who suffer; in scarcity for those who minister to them. But it is also a teacher, a tool, and a generous yardstick for measuring one's career-if we take the time to reflect on it. This is an essay about time and timing as a doctor negotiates the practice of medicine. (J Am Board Fam Med 2016;29:S28-S31.)

Guest editors' note: This Article was commissioned to help prepare attendees for participation in the G. Gayle Stephens Keystone IV Conference. It takes on the challenge of showing the ways in which time features in the lives of physicians and patients and how time impacts the promises of personal physicians.

Keywords: Doctoring, Family Medicine, Family Physician, Health Care Delivery, Personal Physician, Population Health, Primary Care, Professionalism, Social Justice

In January, the Northeast was blanketed by the "Blizzard of 2015." It brought howling winds and 3 feet of drifting snow that effectively shut down all New England for a day and a half. Many of us were given an unexpected holiday; we stayed home, read, listened to the radio, and gazed out our windows as time flew by. It was an intoxicating feeling, truly a gift as disorienting as it was liberating.

Like those who are dislodged by acute illness, terminal diagnosis, vacation, or a Sabbath well observed, I was suddenly released from the expectations of the work-a-day world. I experienced the luxury of time and reflected on the role it plays in the doctor's ability to connect with patients, build trust, and maintain a life-work balance.

We are about to begin a conversation that is riddled with time. Of course, it is about much more than that. Which reminds me of the story

This article was externally peer reviewed.

Submitted 16 December 2015; revised 26 February 2016; accepted 2 March 2016. ME.

From the Seaport Community Health Center, Belfast,

Funding: none.

Conflict of interest: none declared.

Corresponding author: David Loxterkamp, MD, Seaport Community Health Center, 53 Schoodic Dr., Belfast, ME 04915 (E-mail: david.loxterkamp@gmail.com).
Will Miller told on the first night of Keystone IV. His father grew up on a family farm in northeastern Pennsylvania, surrounded by apple orchards and grain fields, earthy smells, and birdsong. Will's dad became a general practitioner; the farm was sold, but the memories and stories persisted.

As fate would have it, Will's son became a farmer. So Will hatched a plan for all 4 generations of Millers (including Will's grandson) to return to the family homestead. There they would collect twigs from the ancient apple trees and graft them into trees in Will's son's orchard in Maine. But his father could not remember the way to the farm or even who owned it. Working with spotty memory and the magic of Google Earth, they reconstructed the route and completed their pilgrimage.

So is Will's story about the passage of time, place, relationships, or technology? Or is it more about the business of life, which forever comes full circle.

\section{Time Out}

When doctors close the examination room door, the room opens up with the potential for some- 
thing extraordinary to happen between a motivated patient and a personal physician. We often glimpse it "over one's shoulder and out of the corner of one's eye," as G. Gayle Stephens ${ }^{1}$ once remarked. For amid the flurry of forms and measurements, our struggle for control, the drumbeat of the schedule, and our urge to intervene, 2 sets of eyes suddenly align and the actors enter into unfettered conversation. The patient tells a story of regret or fear, or explores a deeper wound that has blocked the road to recovery. Such moments fill both the patient and doctor with awe, for they have witnessed new growth sprouting from empty time and find themselves fully engaged with the "other."

The anthropologist Victor Turner described these moments as the liminal stage, that space "betwixt and between" illness and health that catalyzes a change in social status. Donald Schon, in "The Reflective Practitioner," championed this setting as a laboratory for framing the patient's chief complaint. Sandal Mullainathan and Eldar Shafir, a behavioral economist and a cognitive psychologist, examined how the experience of scarcity can consume us, jamming our mental "bandwidth" and robbing us of the "slack" time with which we can otherwise deal with the unexpected. The physician-poet William Carlos Williams writes of his discovery of patients in despair: "They are in trouble; and that is when you are eager to look into things deep, real deep. I would not walk away from those kind of talks for anything; I come away from them so damn stirred myself-I've needed to walk around the block once or twice to settle down, or drive out of the way for a block or two, so I can stop and think."

Despite our yearning for connection, physicians spend, on average, 11 minutes with their patients ${ }^{3}$ and listen to their chief complaint for only 22 seconds before commandeering the interview. ${ }^{4}$ Alas, if only we spent half as much time with our patients as we did attending to their computerized notes, labs, messages, and all the documents that trail their encounter. Such a grim reality leads many to abandon the hamster wheel of fee-for-service general practice and choose direct primary care, where 30 - or 60-minute office visits are more the norm, or the subspecialties that allow for long consultations and a more definitive end to the limitless day.

The most valuable gift we can offer another human being is the time we spend with them. Even in silence or preoccupation, the family doctor's presence defines who we are and what we value.
Then why do we reserve so little of it for ourselves? "Free" time never feels free. And without it-without the necessary time to relax, to ponder or question the status quo-we shortchange ourselves and sell out the future of the profession.

\section{Timing}

On a recent Sunday evening, my neighbor brought his son to see me for a bulge in his neck. I palpated the large rubbery node nestled above the boy's left collar bone and noted a string of smaller cervical and occipital nodes bilaterally. No, he had not had fever, weight loss, sore throat, or skin scratches. So I reassured him that the bump would likely disappear in a couple of weeks.

Because the father was my friend, I took the added precaution of checking a reference text on pediatric lymphadenopathy. It reminded me that this lump-Virchow's node-was located in the dangerous region above the left clavicle that drains the abdomen and thus portends lymphoma. So I called my friend back and encouraged him to consult his son's pediatrician in the morning. That night, the parents slept fitfully, sensing my concern. And over the next 2 weeks, they vacillated between tenuous reassurance and runaway anxiety as family members and consultants raised their concerns and offered advice. The boy's parents walked a knife's edge between fear and reason, first agreeing to blood tests and imaging studies and finally to a node biopsy that ruled out malignancy.

Though the parents were grateful for a good outcome, they rued their loss of control over the timing of their choices. And over the assumptions that were made without them, assumptions that ran ahead of the hard facts or their ambiguous desires. Anguish lay in not knowing when they needed to know and in not knowing how to distinguish between assumption and fact, likelihood and worstcase scenario.

Timing favors the family doctor. It is the tool that prevents our rush to judgment and brakes the urge to test and treat. It is the trigger for assisting patients in behavioral change. It leans heavily on our knowledge of the natural history of a disease, the patients' state of mind, their readiness for intervention, and their level of trust in us. Thus it takes time to perfect, and it relies on a sure knowledge of the patient, his family and friends, and what the diagnosis and treatment means to him, that is, what he is willing to sacrifice and hopes to gain. 
My father wasted little time in the office getting to know his patients. He was a postwar general practitioner, newly in command of penicillin, sulfa, prednisone, and B12. And it did not take him long to dispense them in ground-glass syringes that he kept in his stainless steel sterilizer. On the other hand, he spent hours with his patients on house calls, hospital rounds, and after-hours telephone calls. He saw them routinely about town-at church services, school functions, town celebrations, the grocery or hardware store, weddings and funerals. It was through these unexpected and disarming interactions that he became part of his community's inner circle.

What my father learned is that effective doctoring hinges on a sense of timing grounded in trust. Consent for treatment can easily be gained through the force of the doctor's authority or the patient's fear. But trust requires (and returns) much more: It forges the path for a total stranger to enter the patient's guarded confidence with hope and reassurance.

Trust cannot master the excision of a lymph node. Nor can it change the outcome of a biopsy. But it provides a strong shoulder for patients to brace against while grappling for the strength to carry on. Moreover, it travels both ways. Trust is what doctors need to believe the patient's pain score, or their expressed desire for change, or their denial of suicidal ideation.

My father and I had it easy: We were given access to our patients' most intimate thoughts and feelings by living and working beside them. Every doctor finds their own way, suited to their conditions, to maneuver past the patient's stone wall and to time their interventions with the delicacy of trust and not the hammer of authority and fear.

\section{Life Time}

I recently saw my old patient, Thomas Littlefield (not his real name), during follow-up to his trip to an emergency department. There he was diagnosed with new-onset atrial fibrillation and prescribed blood thinners and a $\beta$-blocker. Tom was a healthy 83 -year-old man, but on that day he admitted to feeling tired and "logy" (that endearing Maine complaint). Otherwise he felt fine, and his vital signs were stable. I reassured him that his symptoms likely reflected his body's response to $\beta$-blockade, loss of an atrial kick, or just plain old age.

So I was shocked to hear, less than a week later, that Tom lay dead in a hospice ward outside the intensive care unit of our referral hospital. Blood thinners had unmasked a bleeding peptic ulcer from which he quickly bled out. This contributed to a myocardial infarction that damaged his heart so severely that it could no longer sustain his life. He entered hospice and died with his wife and children at his side.

I had known the Littlefields for 30 years, since first moving to town. I was their family doctor, and my efforts on their behalf were in direct proportion to the level of trust they placed in me. They, like most of my older patients, made no fuss or demands. So I felt all the more inept and responsible for failing to order a blood count that morning. Mistakes like this are a constant in our line of work (if we choose to see them as more than a "complication"). Nothing brings us to our knees like the blow of harming someone we had intended to help. But mistakes do not define us, no matter how painful. To rise above them, we need the balanced judgment and support of our colleagues, for we all they know the terrain and how quickly it can topple us.

I have long passed the threshold where more of my patients die as friends than strangers. A row of photographs in my office reminds me of those who approached retirement, relocation, infirmary, and death with particular equanimity and grace. I paid attention. I watched them closely and listened to their lament. I've learned that there is no simple or standard way to grow old and die, just as there is no fast track for becoming comfortable in our professional skin. More than ever, we need good friends who know us well and accept us despite it. Medicine is a public career filled with choice and action, and amid the dust and noise there is much we might wish to undo. So it is imperative that we find our balance. And the lessons are everywhere around us: in the lived example of our patients, in mentors like Gayle Stephens, and in words of wisdom that offer comfort during our hour of doubt and insecurity. Thomas Merton" ${ }^{5}$ once journaled, "I am thrown into contradiction. To realize it is mercy, to accept it is love; to help others do the same is compassion." Adam Lindsay Gordon ${ }^{6}$ put it simply: "Life is mostly froth and bubble. Two things stand like stone: kindness in another's trouble; courage in your own."

Time is on the physician's side. It offers us a means to forge connection, leverage change, build trust, and balance our lives. Toward this end, let us pledge to give patients our undivided time. Let us 
create treatment plans that are built on the bedrock of trust. And let us secure these promises with a commitment to regain control over our professional time and the rules that govern it.

If, in 10 years or a hundred, there is no such thing as family medicine, if it yields (again) to forces and events that are larger than ourselves, then the fundamental human values we gave flesh to will, I believe, still go on. Even if our "children"-our trainees-choose not to follow our path, will have made a mighty contribution to whatever comes next. We are doctors and caretakers, first and foremost. We stand with those who bear society's obligation to care for the suffering, crippled, and voiceless.

Over my long career I have "treated" too many of these and saved too few, but I tried to help them all feel a little better. And I found that in the trying I bettered myself. This is what will be remembered on the day of reckoning, when it is time to retire our stethoscopes. I hope we can each of us say that the practice of medicine has given us, and those we cared for, the time of our lives.

\section{References}

1. Stephens GG. Seeing over one's shoulder and out of the corner of one's eye. J Am Board Fam Pract 1989;2:64-7.

2. Williams WC. The doctor stories. Compiled by Robert Coles. New York: New Directions; 1984.

3. Rhoades DR, McFarland KF, Finch WH, Johnson AO. Speaking and interruptions during primary care office visits. Fam Med 2001;33:528-32.

4. Langewitz W, Denz M, Keller A, Kiss A, Rüttimann S, Wossmer B. Spontaneous talking time at start of consultation in outpatient clinic: cohort study. $\mathrm{Br}$ Med J 2002;325:682-3.

5. Merton T, Bochen C. Learning to love: exploring solitude and freedom. The journals of Thomas Merton, vol. 6, 1966-1967. San Francisco: HarperCollins, 1997.

6. Gordon AL. Froth and bubble. Victoria, Australia: The Adam Lindsay Gordon Commemorative Committee. Available from: http://www.adamlindsaygordon.org/ frothbubble.htm. Accessed May 21, 2016. 